\title{
Specific Enzymatic Dephosphorylation of the Retinoblastoma Protein
}

\author{
JOHN W. LUDLOW, $†$ CANDACE L. GLENDENING, DAVID M. LIVINGSTON, \\ AND JAMES A. DECAPRIO* \\ Dana-Farber Cancer Institute and Harvard Medical School, 44 Binney Street, \\ Boston, Massachusetts 02115
}

Received 19 August 1992/Returned for modification 17 September 1992/Accepted 2 October 1992

\begin{abstract}
The retinoblastoma gene product $(\mathbf{R B})$ undergoes cell cycle-dependent phosphorylation and dephosphorylation. Pulse-chase experiments revealed that the change in RB gel electrophoretic migration which occurs near mitosis is due to enzymatic dephosphorylation (J. W. Ludlow, J. Shon, J. M. Pipas, D. M. Livingston, and J. A. DeCaprio, Cell 60:387-396, 1990). To determine the precise timing of RB dephosphorylation and whether a specific phosphatase is active in this process, we have utilized a nocodazole block and release protocol which allows a large population of cells to progress synchronously through mitosis. In such experiments, RB dephosphorylation began during anaphase and continued until complete dephosphorylation was apparent in the ensuing $G_{1}$ period. In addition, late mitotic cell extracts were capable of dephosphorylating $R B$ in vitro. This RB-specific mitotic phosphatase activity was more active in anaphase extracts than in pro- or metaphase extracts, which is consistent with the results obtained in vivo. Okadaic acid and protein phosphatase inhibitors 1 and 2 inhibited this specific RB phosphatase activity. These results suggest a role for serine and threonine phosphoprotein phosphatase type 1 in the late mitotic dephosphorylation of $\mathbf{R B}$.
\end{abstract}

The retinoblastoma susceptibility gene $(R B 1)$ is among the best-characterized tumor suppressor genes. The functional inactivation of both $R B 1$ alleles is linked to the development of retinoblastoma, indicating that it normally operates to control cell growth $(7,8,13,20,26) . R B 1$ may control cell growth in a broad spectrum of tissues, since it is often mutated in a wide variety of human cancers, and the $R B 1$ product, $\mathrm{RB}$, is expressed in most normal mammalian cell types tested.

RB undergoes cell cycle-dependent phosphorylation. During $G_{0} / G_{1}(6,15,17)$, terminal differentiation $(21,36)$, and senescence (41), RB is unphosphorylated or under phosphorylated. Before the onset of DNA synthesis, RB becomes phosphorylated on serine and threonine residues $(6,15,17$, $30,34,40)$. RB undergoes additional changes in its phosphorylation pattern as cells progress into $S$ and again during $G_{2} / M(15)$. RB becomes dephosphorylated near mitosis, but whether this process is truly intramitotic and how it is carried out are unclear (34).

At least one RB function, its ability to bind to simian virus 40 large $T$ antigen ( $T$ ), is controlled by its phosphorylation state (16). T binds only to underphosphorylated RB (33). T-RB complexes, formed in $G_{1}$, dissociate during $S$ and $G_{2}$, when RB becomes phosphorylated, and reform when $R B$ is dephosphorylated after the onset of mitosis (34). The phosphorylation of RB during the $G_{1} / S$ transition and the observation that $T-R B$ binding occurs only in $G_{1}$ suggest that underphosphorylated $\mathrm{RB}$ suppresses growth by contributing to a block to exit from $G_{1}$. This model further suggests that RB-mediated growth suppression can be overcome either by phosphorylation of RB or by T-RB complex formation (17, $33,34)$. In keeping with this hypothesis, microinjection of purified, unphosphorylated $R B$ prevented $G_{1}$ cells of a

\footnotetext{
* Corresponding author.

† Present address: Division of Tumor Biology, University of Rochester Cancer Center, Rochester, NY 14642.
}

continuous line from entering $S$ (23). In this regard, dephosphorylation of $\mathrm{RB}$, after the onset of mitosis, could lead to the recovery of its ability to interact with certain cellular proteins, which are, normally, targets of underphosphorylated RB binding $(9,24)$. This, in turn, might lead to entry into $G_{0}$ and $G_{1}$ and, later on, the decision to enter the next $S$ phase.

In this report, we demonstrate that RB is dephosphorylated late in mitosis and the process begins during anaphase. Furthermore, in vitro analysis of RB dephosphorylation led to the detection of a mitosis-specific phosphatase activity. A large part of this activity is provided by a member of a known protein phosphatase family, PP1, with an established role in the normal regulation of eukaryotic cell division (19, 25).

\section{MATERIALS AND METHODS}

Nocodazole block and release. CV-1P cells were grown in Dulbecco modified Eagle medium (DMEM) (GIBCO) containing $10 \%$ newborn calf serum (NCS; GIBCO) in a $10 \%$ $\mathrm{CO}_{2}$-containing atmosphere at $37^{\circ} \mathrm{C}$. Thirty $90-\mathrm{mm}$ tissue culture dishes were seeded with approximately $10^{6}$ cells each. Sixteen to $40 \mathrm{~h}$ later, hydroxyurea (Sigma) was added to each dish to a final concentration of $0.5 \mathrm{mM}$. Sixteen hours after hydroxyurea addition, the cells were trypsinized and replated at approximately $10^{6}$ cells per $90-\mathrm{mm}$ plate in fresh, drug-free, medium. Eight hours later, a mitotic shake was performed by gentle pipeting to remove mitotic and other loosely adherent cells. The remaining adherent cells were refed with fresh medium containing nocodazole (Janssen) at $100 \mathrm{ng} / \mathrm{ml}$ for $2 \mathrm{~h}$. Then, in a $37^{\circ} \mathrm{C}$ environment room, by using prewarmed equipment, plasticware, and media, a second mitotic shake was performed. The reproducibility of synchrony of exit from mitosis required that all manipulations be performed in the warm room. The cells were collected and centrifuged at $1,000 \times g$ for $4 \mathrm{~min}$ at $37^{\circ} \mathrm{C}$. The cells were washed in media B (DMEM, 10\% NCS, 10 
mM $N$-2-hydroxyethylpiperazine- $N^{\prime}$-2-ethanesulfonic acid [HEPES] [pH 7.4]) and recentrifuged at $1,000 \times g$ for $2 \mathrm{~min}$. The cells were refed with media $\mathrm{B}$ and incubated in the $37^{\circ} \mathrm{C}$ environment room. At timed intervals, beginning at the start of the first wash with media B, the cells were collected, chilled on ice, and divided for various analyses. Chromatin morphology was analyzed in cells fixed in $3.7 \%$ formaldehyde in phosphate-buffered saline. The fixed cells were centrifuged onto glass slides, stained with $4^{1}, 6$-diamidino-2phenylindole (DAPI; Molecular Probes D-1306; $0.5 \mu \mathrm{g} / \mathrm{ml}$ ) for $2 \mathrm{~min}$ at $4^{\circ} \mathrm{C}$, and then observed by UV microscopy. At least 200 cells were counted at each time point in all assays.

Western blotting (immunoblotting). Cells were briefly centrifuged at $16,000 \times g$, washed once in ice-cold Tris-buffered saline (TBS; $20 \mathrm{mM}$ Tris- $\mathrm{HCl}$ [pH 8.0], $120 \mathrm{mM} \mathrm{NaCl}$ ) and lysed with ice-cold EBC buffer ( $20 \mathrm{mM}$ Tris- $\mathrm{HCl}$ [pH 8.0], $120 \mathrm{mM} \mathrm{NaCl}, 0.5 \%$ Nonidet P-40) containing $4 \mathrm{mM} \mathrm{NaF}$, $0.1 \mathrm{nM} \mathrm{Na}$ orthovanadate, and $10 \mu \mathrm{g}$ (each) of aprotinin, leupeptin, $\beta$-glycerolphosphate, and phenylmethylsulfonyl fluoride per ml. Protein concentrations were determined with the Bio-Rad Protein Assay reagent. Approximately 140 $\mu \mathrm{g}$ of protein was separated in each lane of a sodium dodecyl sulfate (SDS)-polyacrylamide gel. After electrophoresis, the proteins were transferred to Immobilon-P (Millipore) according to the manufacturer's directions. The blot was preincubated in TBS containing $5 \%$ bovine serum albumin (BSA) and then incubated overnight in an anti-RB monoclonal antibody (RB-PMG3-245; PharMingen) diluted to 5 $\mu \mathrm{g} / \mathrm{ml}$ in TBS-5\% BSA. Where indicated, the blots were incubated for $2 \mathrm{~h}$ in the monoclonal antibody MPM-2, at a dilution of 1:1,000 in TBS-5\% BSA. Similarly, where noted, blots were exposed to anti-human cyclin $\mathrm{B}$ rabbit serum for $2 \mathrm{~h}$ at a dilution of $1: 4,000$ in TBS-5\% BSA. Blots were washed six times for $10 \mathrm{~min}$ each with TBS-0.5\% BSA. They were then incubated for an additional $30 \mathrm{~min}$ in a second antibody, goat anti-mouse immunoglobulin G-alkaline phosphatase conjugate (Bethesda Research Laboratories) or goat anti-rabbit IgG-alkaline phosphatase conjugate (Bethesda Research Laboratories), at a dilution of 1:7,500 in TBS-5\% BSA, washed six more times for 10 min each with TBS $-0.5 \%$ BSA, and then developed with 5-bromo-4-chloro-3-indolylphosphate toluidinium-nitroblue tetrazolium (Promega).

In vitro phosphatase assay. Synchronization of CV-1P cultures for preparation of extracts for the in vitro phosphatase activity experiments was performed as described previously $(17,34)$. Enrichment of CV-1P cells for $G_{1}$ was achieved by incubating a culture in methionine-free DMEM containing $2 \%$ dialyzed calf serum (GIBCO) for $48 \mathrm{~h}$. S- and $\mathrm{G}_{2}$-phase cells were obtained after methionine starvation for $24 \mathrm{~h}$ followed by incubation for $16 \mathrm{~h}$ in complete DMEM containing $10 \% \mathrm{NCS}$ and $0.5 \mathrm{mM}$ hydroxyurea. S-phase cells were harvested $3 \mathrm{~h}$ after the removal of hydroxyurea. At that time, maximal DNA synthesis, assayed by $\left[{ }^{3} \mathrm{H}\right]$ thymidine incorporation, was noted $(17,34)$. Cells harvested $11 \mathrm{~h}$ after removal of hydroxyurea were enriched for $G_{2}$. Mitotic CV-1P cells were collected by mitotic shake following a 16-h incubation in DMEM-10\% NCS supplemented with $0.4 \mu \mathrm{g}$ of nocodazole per ml. Nocodazole-treated cells were washed three times for $8 \mathrm{~min}$ with warmed $\left(37^{\circ} \mathrm{C}\right)$ DMEM with $10 \%$ NCS to advance them into late mitosis.

Synchronized populations of CV-1P cells were washed three times with ice-cold extraction buffer (40 mM HEPES (pH 7.4), $100 \mathrm{mM} \mathrm{NaCl}$ ) (32). Approximately $2 \times 10^{6}$ cells were then lysed by 10 passages through a 28 -gauge needle in $150 \mu$ l of extraction buffer containing $14 \mathrm{mM} \beta$-mercaptoethanol. The lysate was then incubated for $15 \mathrm{~min}$ at $37^{\circ} \mathrm{C}$.
Following brief centrifugation at $14,000 \times g$, the supernate was removed and the protein concentration of the extract was measured (2). Aprotinin, phenylmethylsulfonyl fluoride, and leupeptin were then added to each supernatant to a final concentration of $10 \mu \mathrm{g} / \mathrm{ml}$ each. Aliquots $(10 \mu \mathrm{g})$ of protein from each of the cell extracts were then each diluted to a final volume of $50 \mu \mathrm{l}$ with extraction buffer containing protease inhibitors. These diluted extracts were then added to $15 \mu \mathrm{l}$ of protein A-Sepharose beads (1:1 [vol/vol] in TBS) containing immunocomplexed ${ }^{32} \mathrm{P}$-labeled RB. Following incubation at $30^{\circ} \mathrm{C}$ for $30 \mathrm{~min}, 30 \mu \mathrm{l}$ of $3 \times$ SDS gel sample buffer was added, and this mixture was boiled for $5 \mathrm{~min}$. The entire sample, consisting of the cell extract; immunocomplexed, labeled RB; protein A-Sepharose; and sample buffer was then loaded onto an 7.5\% SDS-polyacrylamide gel (28) for separation of the proteins.

Where indicated, a mixture of the phosphatase inhibitors (sodium fluoride, sodium $\mathbf{P P}_{\mathrm{i}}$, sodium $\beta$-glycerolphosphate [each at $10 \mathrm{mM}$ final concentration] and sodium orthovanadate [final concentration, $200 \mu \mathrm{M}$ ]) was added to the relevant M-phase extracts.

Radioisotopic labeling and immunoprecipitation. To standardize the quantity of ${ }^{32} \mathrm{P}$-labeled RB immunocomplexed to protein A-Sepharose within each experiment, actively growing CV-1P cells at $\sim 90 \%$ confluency in a $90-\mathrm{mm}$ plastic dish were passaged $1: 3$ approximately $18 \mathrm{~h}$ before labeling. For ${ }^{32} \mathrm{P}$-labeling, cells were maintained in serum-free, phosphate-free DMEM supplemented with ${ }^{32} \mathbf{P}_{\mathbf{i}}$ (carrier free; NEN), as previously described $(29,33)$. Following radiolabeling, the culture was lysed and the clarified supernatant was immunoprecipitated with monoclonal antibody, RBPMG3-245, rabbit anti-mouse immunoglobulin G (Cappel), and protein A-Sepharose. The final, washed immunoprecipitate was divided into eight aliquots. Each aliquot from such a harvest served as the standard quantity of substrate to be used in reaction mixtures within a given experiment, in which RB phosphatase activity was to be measured.

Preparation of serine ${ }^{32} \mathbf{P}$-labeled phosphorylase a. Serine ${ }^{32} \mathrm{P}$-labeled phosphorylase a was prepared by incubating phosphorylase a (Sigma) with phosphorylase kinase (Sigma) at $30^{\circ} \mathrm{C}$ for $15 \mathrm{~min}$ in buffer containing $10 \mathrm{mM}$ Tris- $\mathrm{HCl}(\mathrm{pH}$ 8.2 ), $10 \mathrm{mM}$ sodium glycerolphosphate, $0.1 \mathrm{mM} \mathrm{CaCl}_{2}, 10$ $\mathrm{mM} \mathrm{Mg}$ acetate, and $0.2 \mathrm{mM}\left[{ }^{32} \mathrm{P}\right]$ ATP $(10)$.

\section{RESULTS}

RB dephosphorylation follows nocodazole block and release. To study the precise timing of RB dephosphorylation and how it might be regulated, we adapted a protocol that allows cells to pass synchronously through the various phases of mitosis (27). Cultures of adherent CV-1P (monkey) cells were exposed to hydroxyurea. A mitotic shake was performed $8 \mathrm{~h}$ after initiating drug treatment to remove mitotic and loosely adherent cells. The remaining adherent cells were refed with medium containing nocodazole for $2 \mathrm{~h}$, and the resulting cells, blocked in prometaphase, were collected by a second shake. They were washed free of nocodazole and refed with fresh medium to allow progression through mitosis and into $G_{1}$. Progression through mitosis was monitored by examining the chromosomal pattern of DAPIstained cells. Remarkable synchrony in progression through mitosis occurred. Specifically, $94 \%$ of the cells in nocodazole contained condensed chromosomes, and the majority of them reached metaphase $30 \mathrm{~min}$ after release from the nocodazole block (Fig. 1 and 2). Forty minutes after release, most cells were in anaphase and telophase. Sixty minutes 


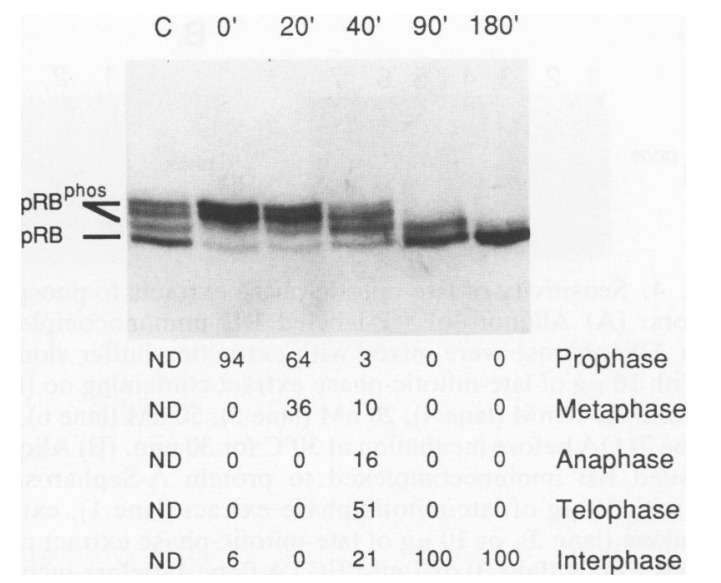

FIG. 1. Western blot for RB from cells treated by nocodazole block and release. Lysates $(140 \mu \mathrm{g})$ prepared from CV-1P cells obtained from the first mitotic shake without added nocodazole (lane C), blocked by nocodazole from the second mitotic shake (lane $0^{\prime}$ ), or released from nocodazole for 20 (lane 20'), 40 (lane 40'), 90 (lane $90^{\prime}$ ), or $180 \mathrm{~min}$ (lane $180^{\prime}$ ) were separated in a SDS-6\% polyacrylamide gel, transferred to Immobilon-P (Millipore), and then blotted with the RB monoclonal antibody RB-PMG3-245 (PharMingen). The percentage of cells in a given phase of mitosis, determined by analyzing the chromosome morphology of cells stained with DAPI, is listed in the column below each lane. ND, not determined.

after nocodazole release, nearly all had reached $G_{1}$, as determined by the presence of decondensed chromatin and the completion of cytokinesis.

A Western blot for RB, performed on a lysate of CV$1 P$ cells collected from the first mitotic shake, revealed several bands (Fig. 1, lane C). We have previously demonstrated that the fastest of them (pRB) contains little, if any, phosphate (33). By contrast, the slower migrating bands (pRB $^{\text {phos}}$ ) are multiply phosphorylated. The nocodazoleblocked cells from the second mitotic shake contained predominantly pRB ${ }^{\text {phos }}$ (Fig. 1 and 2 , lane $0^{\prime}$, and for the first $30 \mathrm{~min}$ after nocodazole release, the RB gel migration pattern did not change (Fig. 1, lane $20^{\prime}$, and Fig. 2, lanes 20' and $\left.30^{\prime}\right)$. However, $40 \mathrm{~min}$ after nocodazole release, when anaphase and telophase cells predominated, at least four forms of RB, including pRB, were apparent (Fig. 1 and 2, lane $\left.40^{\prime}\right)$. When the cells reached $G_{1}, 90 \mathrm{~min}$ after release, only the fastest migrating RB doublet was apparent. A similar schedule for RB dephosphorylation was observed in the primary human fetal lung fibroblast strain WI38; a mink lung fibroblast line, Mv1Lu; as well as in an RB $+/+$ osteosarcoma cell line, U2OS (data not shown).

RB dephosphorylation follows cyclin B disappearance. We analyzed lysates of synchronized $C V-1 P$ cells for $R B$, MPM-2, and cyclin B to correlate RB dephosphorylation with other well-characterized late mitotic events. The monoclonal antibody MPM-2 recognizes several phosphoproteins ranging in size from 47 to $180 \mathrm{kDa}$, apparent only during mitosis (14). Vandré and Borisy (43) have shown that the immunofluorescent signal from cells stained for MPM-2 is negligible during $G_{2}$, peaks during metaphase, and rapidly decreases as cells progress through anaphase. When RB dephosphorylation and MPM-2 band intensity were compared in Western blots, the first evidence of RB dephosphorylation coincided with the first clear signs of diminishing MPM-2 reactivity (Fig. 2, lane $40^{\prime}$, compare top and middle blots). The disappearance of MPM-2 reactivity during an-

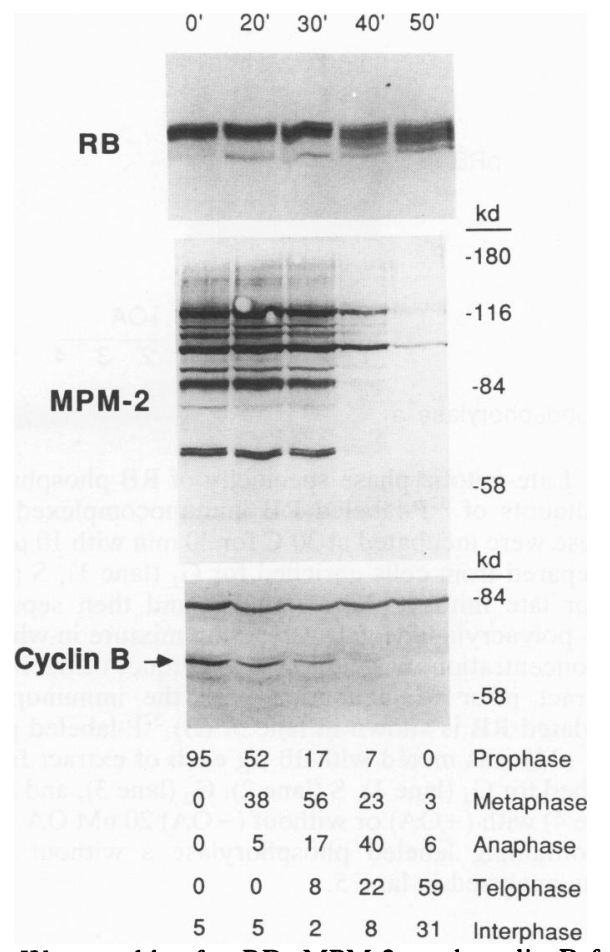

FIG. 2. Western blot for RB, MPM-2, and cyclin B from cells treated by nocodazole block and release. Lysates $(140 \mu \mathrm{g})$ were prepared from cells blocked by nocodazole (lane $\left.0^{\prime}\right)$, and released from nocodazole for 20 (lane $20^{\prime}$ ), 30 (lane $30^{\prime}$ ), 40 (lane 40'), or 50 min (lane $50^{\prime}$ ). Proteins were separated in $6 \%$ (top panel) or $10 \%$ (middle and bottom panel) polyacrylamide-SDS gels before being transferred to Immobilon-P. The top panel was blotted with RB monoclonal antibody, the middle panel was blotted with the MPM-2 monoclonal antibody (14), and the bottom panel was blotted with a polyclonal rabbit antisera to human cyclin $\mathrm{B}(39)$.

aphase, as noted by Western blot analyses, coincides with the immunofluorescence results reported earlier (43).

It has been proposed that RB is a potential substrate for the MPF- $\mathrm{p} 34^{c d c 2}$ kinase $(30,31,42)$. Cyclin $\mathrm{B}$, in association with $\mathrm{p} 34^{c d c 2}$, is required for the entry of cells into mitosis, and its destruction is required for exit from mitosis $(37,38)$. Immunofluorescence data suggest that cyclin $B$ is rapidly degraded at the metaphase to anaphase transition (39). Cyclin B destruction is mediated by ubiquination $(22,44)$. To compare the timing of cyclin B destruction with the dephosphorylation of $\mathrm{RB}$, we utilized a polyclonal antiserum raised against human cyclin B (39). In a Western blot, this serum detected a $60-\mathrm{kDa}$ band from $\mathrm{CV}-1 \mathrm{P}$ cells which comigrated with human cyclin B (data not shown). Cyclin B was present in the nocodazole-blocked CV-1P cells (Fig. 2, bottom blot, lane $0^{\prime}$ ). However, $20 \mathrm{~min}$ after release, there was a clear decrease in the intensity of the signal, followed by complete disappearance at $50 \mathrm{~min}$ (Fig. 2, bottom blot, lanes 20', 30', $40^{\prime}$, and $50^{\prime}$ ). A comparison of the three blots in Fig. 1B suggests that cyclin $B$ disappeared just prior to the onset of $\mathrm{RB}$ dephosphorylation and the beginning of the loss of MPM-2 reactivity.

In vitro assay for RB phosphatase activity. Given the finding of specific RB dephosphorylation intermediates, as well as the abrupt onset of dephosphorylation during anaphase, it seems likely that the process is catalyzed by a specific phosphatase(s). To address this question, an in vitro 
A

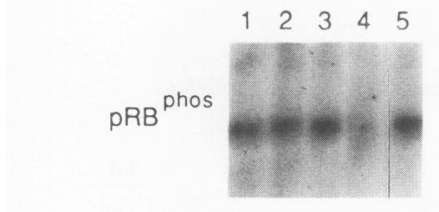

B

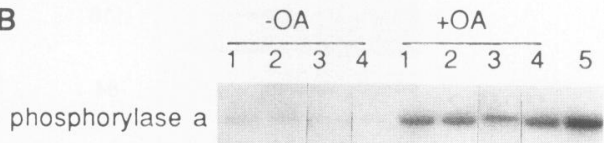

FIG. 3. Late-mitotic-phase specificity of RB phosphatase activity. (A) Aliquots of ${ }^{32} \mathrm{P}$-labeled RB immunocomplexed to protein A-Sepharose were incubated at $30^{\circ} \mathrm{C}$ for $30 \mathrm{~min}$ with $10 \mu \mathrm{g}(50 \mu \mathrm{l})$ of extract prepared from cells enriched for $G_{1}$ (lane 1), $S$ (lane 2), $G_{2}$ (lane 3), or late mitotic phase (lane 4) and then separated in a SDS-7.5\% polyacrylamide gel. A reaction mixture in which OA $(20$ $\mathrm{nM}$ final concentration) was added to an aliquot of the late-mitoticphase extract prior to incubation with the immunoprecipitated phosphorylated RB is shown in lane 5. (B) ${ }^{32} \mathrm{P}$-labeled phosphorylase a $(0.3 \mathrm{nM})$ was mixed with $10 \mu \mathrm{g}$ each of extract from CV-1P cells enriched for $G_{1}$ (lane 1$), S$ (lane 2), $G_{2}$ (lane 3), and late mitotic phase (lane 4) with (+OA) or without (-OA) $20 \mathrm{nM}$ OA. A reaction mixture containing labeled phosphorylase a without added cell extract was analyzed in lane 5.

assay to characterize RB phosphatase activity was developed. Extracts of unlabeled $G_{1}, S, G_{2}$, or late-mitotic-phase CV-1P cells were mixed with ${ }^{32} \mathrm{P}$-labeled RB immunoprecipitated from unsynchronized CV-1P cells. Only the latemitotic-phase extract demonstrated specific RB dephosphorylation activity under the conditions employed (Fig. 3A, lane 4). In contrast, all extracts displayed phosphorylase a dephosphorylation activity (Fig. 3B). A similar experiment, performed with $\left[{ }^{35}\right.$ S $]$ methionine labeled $\mathrm{RB}$ as substrate, demonstrated a shift from the slower migrating, $\mathrm{pRB}^{\text {phos }}$, to the fastest migrating, underphosphorylated, pRB species, suggesting that the disappearance of phosphorylated RB is the result of specific dephosphorylation and not degradation of the protein (data not shown). Furthermore, incubation of in vivo-synthesized ${ }^{32} \mathrm{P}-\mathrm{RB}$, isolated by immunoprecipitation, in buffer without added cell extract did not result in RB dephosphorylation, indicating that a cellular phosphatase was not coprecipitated with the labeled substrate (data not shown). Finally, as demonstrated in Fig. 3A, ${ }^{32} \mathrm{P}$-labeled RB disappeared when incubated with the late-mitotic-phase extract, except when the reaction was carried out in the presence of a known specific phosphatase inhibitor, okadaic acid (OA) (compare lanes 4 and 5).

Sensitivity of late-mitotic-phase phosphatase to inhibitors. Multiple serine and threonine protein phosphatases have been identified (11). Each can be distinguished by its sensitivity to certain inhibitors $(4,11,12)$. OA inhibits protein phosphatase 1 (PP1) at nanomolar concentrations (e.g., 10 $\mathrm{nm}$ ) and phosphoprotein phosphatase type 2A (PP2A) at subnanomolar concentrations (e.g., $0.5 \mathrm{nM}$ ). PP1 can be specifically inhibited by thermostable protein phosphatase inhibitors type 1 (I1) and 2 (I2), while members of the type 2 group (PP2A, PP2B, and PP2C) cannot. PP2A does not require divalent cations for activity, while PP2B and PP2C show an absolute requirement for $\mathrm{Ca}^{2+}$ and $\mathrm{Mg}^{2+}$, respectively. As shown in Fig. 4, the in vitro RB phosphatase activity in late-mitotic-phase extracts was completely inhibited by $\geq 10 \mathrm{nM}$ OA (Fig. 4A), but not by added EDTA or
A.

B.

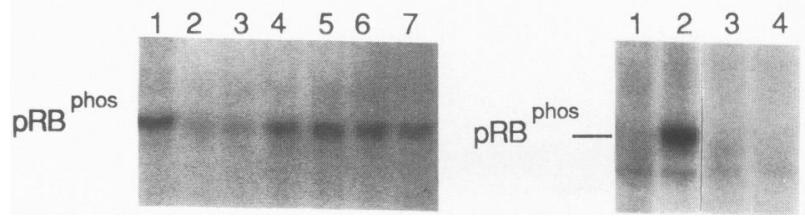

FIG. 4. Sensitivity of late-mitotic-phase extracts to phosphatase inhibitors. (A) Aliquots of ${ }^{32}$ P-labeled RB immunocomplexed to protein A-Sepharose were mixed with extraction buffer alone (lane 1) or with $10 \mu \mathrm{g}$ of late-mitotic-phase extract containing no (lane 2), $2 \mathrm{nM}$ (lane 3), $10 \mathrm{nM}$ (lane 4), $20 \mathrm{nM}$ (lane 5), $50 \mathrm{nM}$ (lane 6), or 100 $\mathrm{nM}$ (lane 7) OA before incubation at $30^{\circ} \mathrm{C}$ for $30 \mathrm{~min}$. (B) Aliquots of ${ }^{32} \mathrm{P}$-labeled RB immunocomplexed to protein A-Sepharose were mixed with $10 \mu \mathrm{g}$ of late-mitotic-phase extract (lane 1), extraction buffer alone (lane 2), or $10 \mu \mathrm{g}$ of late-mitotic-phase extract containing $1 \mathrm{mM}$ EDTA (lane 3) or $1 \mathrm{mM}$ EGTA (lane 4) before incubation.

EGTA (Fig. 4B). These results suggest that the RB phosphatase activity in late mitotic extracts is, at least in part, the product of one or more PP1-like species.

The specificity of the in vitro phosphatase assay was further studied by comparing the abilities of purified PP1 and PP2A to dephosphorylate RB. Both enzymes were able to dephosphorylate the phosphorylase a substrate and, as predicted, purified PP1, but not PP2A, was inhibited by I1 (data not shown). In contrast, only purified PP1 dephosphorylated immunoprecipitated pRB phos $^{\text {(Fig. 5). }}$

The results from experiments shown in Fig. 4 and 5 suggest that PP1 is the major component of the RB phosphatase activity. Furthermore, the results of in vivo experiments shown in Fig. 1 and 2, demonstrate that RB is dephosphorylated in late mitosis. This could result from an increase in PP1 phosphatase activity during late mitosis. To determine whether the RB phosphatase activity increases as cells progress from early to late mitosis, we compared the inhibition profile of extracts prepared from pro- and metaphase cells (20 min after nocodazole release), to those from ana- and telophase extracts (45 min) with ${ }^{32} \mathrm{P}$-labeled RB as substrate. $\mathrm{OA}$ at $10 \mathrm{nM}$ inhibited nearly all phosphatase activity at both intervals (Table 1 ). However, OA at $0.5 \mathrm{nM}$ completely inhibited all activity in the pro- and metaphase extract but only partially inhibited the ana- and telophase extract. Similarly, I1 (100 nM) and I2 (100 $\mu \mathrm{M})$ inhibited most of the activity in both extracts. However, neither I1 nor 12 , when studied at a 10 -fold-reduced concentration (10 nM and $10 \mu \mathrm{M}$, respectively), inhibited the ana- and telophase extracts, but both could partially inhibit the phosphatase activity in the early extracts. These results are consistent with the interpretation that the abundance of PP1 activity

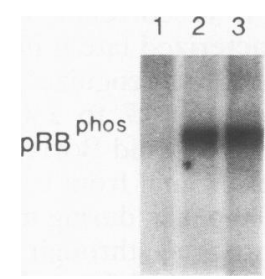

FIG. 5. Sensitivity of RB to purified PP1 and PP2A. A total of $0.3 \mathrm{U}$ of purified PP1 (lane 1) or PP2A (lane 2) was added to aliquots of immunoprecipitated ${ }^{32}$ P-labeled RB. Neither enzyme was added to the reaction mixture analyzed in lane 3 . All reaction mixtures were incubated at $30^{\circ} \mathrm{C}$ for $30 \mathrm{~min}$ in buffers identical to those used in Fig. 3 . 
TABLE 1. Inhibitor profile of in vitro phosphatase activity in early- and late-mitotic-phase extracts

\begin{tabular}{|c|c|c|c|c|c|c|}
\hline \multirow{3}{*}{ Mitotic extract } & \multicolumn{6}{|c|}{$\%$ Inhibition of phospatase activity ${ }^{a}$} \\
\hline & \multicolumn{2}{|c|}{ OA } & \multicolumn{2}{|c|}{ I1 } & \multicolumn{2}{|c|}{12} \\
\hline & $\begin{array}{c}10 \\
\mathrm{nM}\end{array}$ & $\begin{array}{l}0.5 \\
\mathrm{nM}\end{array}$ & $\begin{array}{l}100 \\
\mathrm{nM}\end{array}$ & $\begin{array}{c}10 \\
\mathrm{nM}\end{array}$ & $\begin{array}{l}100 \\
\mu \mathrm{M}\end{array}$ & $\begin{array}{r}10 \\
\mu M\end{array}$ \\
\hline Pro- and metaphase & 83 & 100 & 60 & 26 & 74 & 32 \\
\hline Ana- and telophase & 100 & 44 & 52 & 0 & 68 & 0 \\
\hline
\end{tabular}

a The in vitro phosphatase assay was performed with extracts prepared from cells treated with the nocodazole block and release protocol. The proand metaphase extracts were prepared from cells obtained $20 \mathrm{~min}$ after nocodazole release, and the ana- and telophase extracts were from cells obtained $45 \mathrm{~min}$ after nocodazole release. The assay was performed with the indicated final concentrations of $\mathrm{OA}, \mathrm{I} 1$, and $\mathrm{I} 2$ present in the reaction mixture. ${ }^{32}$ P-labeled RB was localized by autoradiography of the SDSpolyacrylamide gel with preflashed film, and densitometry was performed to quantitate changes in RB-labeled phosphate content. Percent inhibition of phosphatase activity was determined by measuring the percentage of phosphorylated RB remaining after incubation compared with that in the control reactions carried out in the absence of extract or inhibitor.

increased from early to late mitosis. This increase in PP1 phosphatase activity correlates with the RB dephosphorylation observed in vivo during anaphase (Fig. 1 and 2).

\section{DISCUSSION}

Using the nocodazole block and release protocol, we have found that RB dephosphorylation begins during anaphase. The nocodazole block and release protocol yielded a reproducibly synchronous passage of cells through mitosis. As shown in two different experiments (Fig. 1 and 2), approximately $65 \%$ of all cells were in anaphase or telophase $40 \mathrm{~min}$ after nocodazole release. A similar delay in initiating RB dephosphorylation was noted in the detached cells from the first mitotic shake that had never been exposed to nocodazole (data not shown). However, because the population of cells from the first mitotic shake was not as tightly synchronized as the drug-exposed population from the second mitotic shake, it was difficult to determine the precise point in mitosis when dephosphorylation began without the use of nocodazole. The nocodazole block and release protocol is useful for studying events in mid to late mitosis, such as cyclin B destruction (metaphase to anaphase) and loss of MPM-2 reactivity (anaphase). The loss of MPM-2 reactivity coincides with the dephosphorylation of RB and may also be due to the loss of phosphorylated epitopes by a phosphatase activated late in mitosis. These two events clearly follow the loss of cyclin B and places these events in late mitosis.

Using in vivo-synthesized and phosphorylated RB as substrate, we determined that extracts prepared from latemitotic-phase cells contain a specific phosphatase activity. The results of inhibitor studies suggest that the major phosphatase activity was PP1 and that there was an apparent increase in PP1 activity as cells progressed from early to late mitosis. These results and the observation that purified PP1, and not PP2A, is able to dephosphorylate $R B$ in vitro suggest that PP1 activity participates in the specific, orderly dephosphorylation of RB late in mitosis. It does not rule out the possibility that other phosphatases also participate in the RB dephosphorylation process.

These results do not address the question of how the relevant mitotic RB phosphatase(s) is specifically activated. It is possible that cyclical expression or activation of inhibitor 2 (5) or a change in the subcellular localization of PP1
(19) could account for the apparent activation of PP1 activity that results in the dephosphorylation of RB in anaphase.

Recent observations have led to some insight into how exit from mitosis is controlled (35). In particular, work from several laboratories suggests that the separation of sister chromatids is dependent on the activity of a PP1 species (1, 18, 25). In Schizosaccharomyces pombe, Aspergillus nidulans, and Drosophila melanogaster, the genetics imply that a PP1 species must become active to complete mitosis. What is not known is the nature of the relevant mitotic substrates for the PP1 activity. Their identity would, presumably, shed light on the mechanisms controlling certain late mitotic events. In this regard, RB may be among the first PP1 mitotic substrates identified, although it has also been suggested that lamins and vimentin are also specifically dephosphorylated by PP1 active during anaphase (3). Given this, it will be important to determine whether the dephosphorylation of RB actually contributes to one or more mitotic events.

The multimodal aspect of RB dephosphorylation (the initiation of RB dephosphorylation beginning in late mitosis and the last part of which likely occurs in $G_{1}$ [Fig. 1]) suggests that there may be several functional consequences of this process. If the phosphorylated intermediates in the dephosphorylation process, detected primarily during late mitosis, are also active, then one wonders whether these two RB species, partially dephosphorylated and unphosphorylated, have different functions. If so, the proper timing of dephosphorylation might contribute to orderly progression out of mitosis and into a normally controlled $G_{0}$ or $G_{1}$ period. Experiments aimed at determining whether there are significant differences in function among these species are in progress.

\section{ACKNOWLEDGMENTS}

MPM-2 was a generous gift of Portu Rao, and anti-human cyclin $B$ rabbit serum was a generous gift of Jonathan Pines. Purified serine and threonine protein phosphatase type 1 were kindly provided by David Brautigan and Bruce Martin. Purified protein serine and threonine protein phosphatase type $2 \mathrm{~A}$ and purified protein phosphatase type 1 inhibitor (I1) were generously provided by David Lee and Jonathan Chernoff. Recombinant 12 was the kind gift of Anna DePaoli-Roach. We thank David Pallas and Mark Ewen for a number of helpful discussions.

This work was supported by grants to D.M.L. and J.A.D. (K11 CA01385-03) from the National Cancer Institute. J.W.L. was supported by NRSA CA-08616-02.

\section{REFERENCES}

1. Axton, J. M., V. Dombradi, P. W. T. Cohen, and D. M. Glover. 1990. One of the protein phosphatase 1 isoenzymes in drosophila is essential for mitosis. Cell 63:33-46.

2. Bradford, M. M. 1976. A rapid and sensitive method for the quantitation of microgram quantities of protein utilizing the principle of protein-dye binding. Anal. Biochem. 72:248-254.

3. Brautigan, D. L., A. Fernandez, and N. J. C. Lamb. 1989. Microinjection of protein phosphatase type-1 selectively alters fibroblast functions and in vivo phosphorylation. Adv. Protein Phosphatases 5:547-566.

4. Brautigan, D. L., and C. L. Shriner. 1988. Methods to distinguish various types of protein phosphatase activity. Methods Enzymol. 159:339-356.

5. Brautigan, D. L., J. Sunwoo, J. Labbe, A. Fernandez, and N. J. C. Lamb. 1990. Cell cycle of oscillation of phosphatase inhibitor-2 in rat fibroblasts coincident with $\mathrm{p} 34^{\text {cdc }}$ restriction. Nature (London) 344:74-78.

6. Buchkovich, K., L. A. Duffy, and E. Harlow. 1989. The retinoblastoma protein is phosphorylated during specific phases of the cell cycle. Cell 58:1097-1105.

7. Cavenee, W. K., T. P. Dryja, R. A. Phillips, W. F. Benedict, R. 
Godbout, B. L. Gallie, A. L. Murphree, L. C. Strong, and R. L. White. 1983. Expression of recessive alleles by chromosomal mechanisms in retinoblastoma. Nature (London) 305:779-784.

8. Cavenee, W. K., M. F. Hansen, M. Nordenskjold, E. Kock, I. Maumenee, J. Squire, R. A. Phillips, and B. L. Gallie. 1985. Genetic origin of mutations predisposing to retinoblastoma. Science 228:501-503.

9. Chellappan, S. P., S. Hiebert, M. Mudryj, J. M. Horowitz, and J. R. Nevins. 1991. The E2F transcription factor is a cellular target for the RB protein. Cell 65:1053-1061.

10. Cohen, P., S. Alemany, B. A. Hemmings, T. J. Resink, P. Stralofors, and H. L. Tung. 1988. Protein phosphatase-1 and protein phosphatase-2 A from rabbit skeletal muscle. Methods Enzymol. 159:390-416.

11. Cohen, P., and P. W. T. Cohen. 1989. Protein phosphatases come of age. J. Biol. Chem. 264:21435-21438.

12. Cohen, P. W. T., S. Klumpp, and D. L. Schelling. 1989. An improved procedure for identifying and quantitating protein phosphatases in mammalian tissues. FEBS Lett. 250:596-600.

13. Comings, D. E. 1973. A general theory of carcinogenesis. Proc. Natl. Acad. Sci. USA 70:3324-3328.

14. Davis, F. M., T. Y. Tsao, S. K. Fowler, and P. N. Rao. 1983. Monoclonal antibodies to mitotic cells. Proc. Natl. Acad. Sci. USA 80:2926-2930.

15. DeCaprio, J. A., Y. Furukawa, F. Ajchenbaum, J. D. Griffin, and D. M. Livingston. 1992. The retinoblastoma-susceptibility gene product becomes phosphorylated in multiple stages during cell cycle entry and progression. Proc. Natl. Acad. Sci. USA 89:1795-1798

16. DeCaprio, J. A., J. W. Ludlow, J. Figge, J.-Y. Shew, C.-M. Huang, W.-H. Lee, E. Marsilio, E. Paucha, and D. M. Livingston. 1988. SV40 large T antigen forms a specific complex with the product of the retinoblastoma susceptibility gene. Cell 54:275-283.

17. DeCaprio, J. A., J. W. Ludlow, D. Lynch, Y. Furukawa, J. Griffin, H. Piwnica-Worms, C.-M. Huang, and D. M. Livingston. 1989. The product of the retinoblastoma susceptibility gene has properties of a cell cycle regulatory element. Cell 58:1085-1095.

18. Doonan, J. H., and N. R. Morris. 1989. The bimG gene of Aspergillus nidulans, required for completion of anaphase, encodes a homolog of mammalian phosphoprotein phosphatase 1. Cell 57:987-996.

19. Fernandez, A., D. L. Brautigan, and N. J. C. Lamb. 1992. Protein phosphatase type 1 in mammalian cell mitosis: chromosomal localization and involvement in mitotic exit. J. Biol. Chem. 116:1421-1430.

20. Friend, S. H., R. Bernards, S. Rogelj, R. A. Weinberg, J. M. Rapaport, D. M. Alberts, and T. P. Dryja. 1986. A human DNA segment with properties of the gene that predisposes to retinoblastoma and osteosarcoma. Nature (London) 323:643-646.

21. Furukawa, Y., J. A. DeCaprio, A. Freedman, Y. Kanakura, M Nakamura, T. J. Ernst, D. M. Livingston, and J. D. Griffin. 1990. Expression and state of phosphorylation of the retinoblastoma susceptibility gene product in cycling and noncycling human hematopoietic cells. Proc. Natl. Acad. Sci. USA 87: 2770-2774.

22. Glotzer, M., A. W. Murray, and M. W. Kirschner. 1991. Cyclin is degraded by the ubiquitin pathway. Nature (London) 349: 132-138.

23. Goodrich, D. W., N. P. Wang, Y. Qian, E. Y. Lee, and W.-H. Lee. 1991. The retinoblastoma gene product regulates progression through the G1 phase of the cell cycle. Cell 67:293-302.

24. Kaelin, W. G. J., W. Krek, W. R. Sellers, J. A. DeCaprio, F. Ajchenbaum, C. S. Fuchs, T. Chittenden, Y. Li, P. J. Farnham, M. A. Blanar, D. M. Livingston, and E. K. Flemington. 1992. Expression cloning of a cDNA encoding a retinoblastomabinding protein with E2F-like properties. Cell 70:351-364.

25. Kinoshita, N., H. Ohkura, and M. Yanagida. 1990. Distinct, essential roles of type 1 and $2 \mathrm{~A}$ protein phosphatases in the control of the fission yeast cell division cycle. Cell 63:405-415.

26. Knudson, A. G., Jr. 1971. Mutation and cancer: statistical study of retinoblastoma. Proc. Natl. Acad. Sci. USA 68:820-823.

27. Kuriyama, R., G. Keryer, and G. G. Borisy. 1984. The mitotic spindle of Chinese hamster ovary cells isolated in taxol-containing medium. J. Cell Sci. 66:265-275.

28. Laemmli, U. K. 1970. Cleavage of structural proteins during the assembly of the head of bacteriophage T4. Nature (London) 227:680-685.

29. Laiho, M., J. A. DeCaprio, J. W. Ludlow, D. M. Livingston, and J. Massague. 1990. Growth inhibition by TGF- $\beta$ linked to suppression of retinoblastoma protein phosphorylation. Cell 62:175-185.

30. Lees, J. A., K. J. Buchovich, D. R. Marshak, C. W. Anderson, and E. Harlow. 1991. The retinoblastoma protein is phosphorylated on multiple sites by human cdc2. EMBO J. 10:4279-4290.

31. Lin, B. T., S. Gruenwald, A. O. Morla, W.-H. Lee, and J. Y. J. Wang. 1991. Retinoblastoma cancer suppressor gene product is a substrate of the cell cycle regulator cdc2 kinase. EMBO J. 10:857-864.

32. Ludlow, J. W. 1992. Selective ability of S-phase cell extracts to dephosphorylate SV40 large T antigen in vitro. Oncogene 7:1011-1014.

33. Ludlow, J. W., J. A. DeCaprio, C. Huang, W.-H. Lee, E. Paucha, and D. M. Livingston. 1989. SV40 Large T antigen binds preferentially to an underphosphorylated member of the retinoblastoma susceptibility gene product family. Cell 56:57-65.

34. Ludlow, J. W., J. Shon, J. M. Pipas, D. M. Livingston, and J. A. DeCaprio. 1990. The retinoblastoma susceptibility gene product undergoes cell cycle-dependent dephosphorylation and binding to and release from SV40 large T. Cell 60:387-396.

35. McIntosh, J. R., and M. P. Koonce. 1989. Mitosis. Science 246:622-628.

36. Mihara, K., X. Cao, A. Yen, S. Chandler, B. Driscoll, A. L. Murphree, A. T'Ang, and Y. Fung. 1989. Cell cycle-dependent regulation of phosphorylation of the human retinoblastoma gene product. Science 246:1300-1303.

37. Minshull, J., J. J. Blow, and T. Hunt. 1989. Translation of cyclin mRNA is necessary for extracts of activated xenopus eggs to enter mitosis. Cell 56:947-956.

38. Murray, A. W., M. J. Solomon, and M. W. Kirschner. 1989. The role of cyclin synthesis and degradation in the control of maturation promoting factor activity. Nature (London) 339:280 286.

39. Pines, J., and T. Hunter. 1991. Human cyclins A and B1 are differentially located in the cell and undergo cell cycle-dependent nuclear transport. J. Cell Biol. 115:1-17.

40. Shew, J., N. Ling, X. Yang, O. Fodstad, and W.-H. Lee. 1989. Antibodies detecting abnormalities of the retinoblastoma susceptibility gene product ( $\left.\mathrm{pp} 110^{\mathrm{RB}}\right)$ in osteosarcomas and synovial sarcomas. Oncogene Res. 1:205-214.

41. Stein, G. H., M. Beeson, and L. Gordon. 1990. Failure to phosphorylate the retinoblastoma gene product in senescent human fibroblasts. Science 249:666-669.

42. Taya, Y., H. Yasuda, M. Kamijo, K. Nakaya, Y. Nakamura, Y. Ohba, and S. Nishimura. 1989. In vitro phosphorylation of the tumor suppressor gene RB protein by mitosis-specific histone H1 kinase. Biochem. Biophys. Res. Commun. 164:580-586.

43. Vandré, D. D., and G. G. Borisy. 1989. Anaphase onset and dephosphorylation of mitotic phosphoproteins occur concomitantly. J. Cell Sci. 94:245-258.

44. Whitfield, W. G. F., C. Gonzalez, G. Maldonado-Codina, and D. M. Glover. 1990. The A- and B-type cyclins of Drosophila are accumulated and destroyed in temporally distinct events that define separable phases of the G2-M transition. EMBO J. 9:2563-2572. 